\title{
IMÁGENES, NOBLEZA Y TRANSFORMACIÓN CULTURAL. EVOLUCIÓN DE LA POSESIÓN DE PINTURAS, ESCULTURAS Y TAPICES DE TRES GENERACIONES DE LA CASA DUCAL DEL INFANTADO (1531-1566) ${ }^{1}$
}

Data recepción: 2009/11/05

Data aceptación: 2010/05/10

Contacto autor: aa1gorar@uco.es
Roberto González Ramos

Universidad de Córdoba

\section{RESUMEN}

El presente artículo versa sobre la posesión de imágenes de la casa ducal del Infantado. En tanto que uno de los títulos más importantes de la Corona de Castilla en el siglo XVI, es indudable el interés de un estudio sobre dicho aspecto. Pero más aún si consideramos un análisis no sólo de los objetos de esa categoría (pinturas, esculturas, tapices, etc.), sino de su significado en cuanto a que su posesión pudiera señalar un mayor o menor grado en el conocimiento y adopción de modelos culturales moderno-renacentistas. Además, se trata de un estudio comparativo que pretende valorar la evolución de los modos de "poseer" imágenes a lo largo de las tres primeras generaciones de los duques del Infantado en el Quinientos.

Palabras clave: Coleccionismo, Duques del Infantado, Diego Hurtado de Mendoza, Î́nigo López de Mendoza, marqués del Cenete

\section{ABSTRACT}

This study discusses the collection of artworks at the House of the Dukes of the Infantado, a subject that is interesting in itself, given the dukedom's status as one of the most important in sixteenth-century Castile. Further interest is raised, however, by the fact that the paper considers both the objects that make up the collection (paintings, sculptures and tapestries, etc) and the extent to which their acquisition is indicative of a knowledge and adoption of modern-Renaissance cultural models on the part of the collection's owners. The paper also provides a comparative study that aims to assess the manner in which the acquisition of artworks in the sixteenth century by the first three generations of the dukes of the Infantado evolved.

Keywords: collecting, the Dukes of the Infantado, Diego Hurtado de Mendoza, Inigo Lopez de Mendoza, the Marquis of Cenete

Este estudio trata sobre las imágenes que poseyeron y utilizaron tres de los integrantes de la casa ducal del Infantado. Estos tres personajes fueron del III duque Diego Hurtado de Mendoza (1461-1531), el IV duque Íñigo López de Mendoza (1493-1566) y el hijo de éste el conde de Saldaña Diego Hurtado de Mendoza (15201560). Son los tres primeros, dentro de la dinastía de la casa ducal y cabeza de los Mendoza, de los que conocemos los inventarios de bienes realizados a su fallecimiento. El estudio de esos inventarios y otros documentos afines nos per- mite conocer con bastante exactitud cuáles fueron los bienes que acumularon al final de sus vidas $\mathrm{y}$, en concreto, las pinturas, los tapices y las esculturas.

Lo más interesante de la información que nos ofrecen dichas fuentes es que nos permite acercarnos al análisis del desarrollo que en estas tres generaciones se produjo en la adopción de los modos culturales renacentistas y en la adopción de los caracteres externos de la nobleza cortesana y de la modernidad. En tanto que miembros de una de las casas nobiliarias más 
destacadas de su tiempo, el análisis de este caso no carece de interés. Pero más interés tiene, a nuestro parecer, que este análisis se haga desde una perspectiva que pretende aunar el acercamiento a los valores de cantidad, tipología, uso de los bienes y su significado, y la interpretación de los datos de forma intergeneracional, evolutiva. Se trata, pues, de un estudio comparativo diacrónico que, dadas las restricciones de espacio, debe atender aquí a una única categoría de aquellos bienes que más nos interesa desde el punto de vista de la Historia del Arte: las imágenes.

Lo cierto es que nos interesa no tanto el estudio de todas y cada una de las categorías de los objetos que poseyeron estos individuos, como de las que puedan señalarnos diversos patrones de conducta cultural que sabemos hoy que eran indicativos de una especial comprensión de los valores culturales de la cortesanía y el Humanismo de la temprana Edad Moderna. Desde luego, hay distintos tipos de objetos que podrían indicar el conocimiento y comprensión de dichos patrones o valores, pero queremos ahora centrarnos en las imágenes, en tanto que indicadoras en grado máximo de los mismos. Además, queremos evitar hacer alusión al estudio del coleccionismo artístico, puesto que éste pertenece a un grado muy desarrollado de esos comportamientos culturales que traía de la mano la nueva cultura y que, en prácticamente ningún caso de los que expondremos, podremos llegar a encontrar. El entramado historiográfico normalmente se refiere al concepto de coleccionismo remitiéndonos a un proceso evolutivo que sitúa la tesaurización en la Edad Media, y el coleccionismo arqueológico, naturalista o de las "cámaras de maravillas" (las wunderkammern centroeuropeas) en el siglo XVI, como precedentes de un coleccionismo que tendrá su culminación en las galerías de pinturas del siglo XVII ${ }^{2}$. Este modelo ideal no se corresponde con la realidad de la alta nobleza hispana del siglo XVI. La posesión de artefactos culturales y de prestigio tales como las imágenes no podía responder a conceptos tan desarrollados como el de coleccionismo, según hemos dicho. Un análisis global de los usos de las imágenes de entre las propiedades de los "grandes" hispanos debería ofrecernos modelos de interpretación más concretos, pero está aún por hacer. Lo que aquí se ofrece es un estudio evolutivo centrado en un caso concreto y significativo por la relevancia social de la Casa del Infantado, cabeza de unos Mendoza que suelen ser considerados por la historiografía artística como los adelantados de la introducción de los modos culturales de la modernidad en la Península Ibérica ${ }^{3}$. Se pretende, de esa forma, atender a un caso modélico. Pero no es modélico, a pesar de lo dicho, por tratarse de una singular excepción a la norma, sino por, precisamente, tratarse de un caso común en el que la alta nobleza hispana muestra cómo y a qué ritmos podían incorporarse los modelos de la civilización europea moderno-renacentista en un arco cronológico determinado 4 .

\section{Los personajes}

El III duque del Infantado, Diego Hurtado de Mendoza, nació en el castillo de Arenas en 1461 y falleció en Guadalajara en 1531. Fue hijo del II duque y de María de Luna. Su educación estuvo dirigida por un ayo hidalgo y centrada en las virtudes caballerescas. Vivió en medio de varias generaciones de sus familiares más belicosos y se formó en los principios de la nobleza guerrera. Tuvo numerosas ocasiones de llevar a la práctica esos principios, en guerras civiles y en la guerra de Granada ${ }^{5}$. Heredó de su padre el Infantado en 1500 y, de su madre, el mayorazgo de Álvaro de Luna, personaje que fue rehabilitado por Isabel la Católica en 1506. Según nos lo describen los cronistas de la casa ducal, fue un hombre muy religioso y muy aficionado al culto divino y, de hecho, llegó a habilitar el Salón de los Linajes de su palacio para que sirviese de capilla. Contrató músicos a sueldo para la celebración de misas y se preocupó de adornar convenientemente y con todo lujo el altar y oficiantes, incluso encargando esculturas, custodia y andas de plata con que completar el aparato litúrgico ${ }^{6}$. Esta pasión por el ceremonial se reflejaba también en el patio del palacio, donde se escenificaban procesiones, utilizando el grueso de sus tapices para adornarlo. Fue muy cercano a Fernando el Católico, quien le otorgó una esposa de su estirpe para su primogénito. Posteriormente, al servicio de Carlos V, debió recibir y acoger en su palacio al rey de Francia Francisco I, quien había 
caído preso en la batalla de Pavía en 1525. La estancia del rey francés en el palacio del Infantado fue cantada por Luis Zapata en su Carlo Famoso, dejando un ingenioso texto poético en el que se describe un tanto fantasiosamente el brillo de la corte ducal de Guadalajara7. Murió el duque a los 70 años, "vuelto a un 'Ecce Homo' muy devoto, que estaba en la cabecera de su lecho"8.

Înigo López de Mendoza, hijo del anterior y de María Pimentel, fue el IV duque del Infantado. Nació en Guadalajara en 1493, y allí murió en 1566. También se le asignó un caballero para que lo formase en el mundo de la espada y la caza, aunque tuvo la ocasión de extender su educación al de las letras, rodeándose de eruditos y humanistas, aprendiendo latín y humanidades. Siguió muy de cerca la figura de su antepasado el marqués de Santillana, sumergiéndose en el mundo de la cultura libresca y apoyando a diversos estudiosos con los que formó un pequeño círculo en su residencia. De su propia pluma tenemos dos escritos, uno de ellos un libro titulado Memorial de cosas notables $^{10}$. Imbuido ya de la cultura cortesana renacentista, fue aficionado a la ejecución musical personal: "gran músico, tocaba todos los instrumentos con suficiencia, en especial en puntear un laúd, era consumado"11, lo cual no es óbice para que entre sus aficiones predilectas figurasen las armas, la caza y la equitación. Contrajo matrimonio con la sobrina de Fernando el Católico Isabel de Aragón, quien aportó una dote extraordinaria y los beneficios que son de imaginar a la casa ducal ${ }^{12}$. Representó a su anciano y enfermo padre en diversas ocasiones, como en el recibimiento a Francisco I, y con motivo de la jornada de la coronación imperial de Carlos $V$ en Bolonia ${ }^{13}$, y fue caballero de la orden del Toisón de oro. En 1560 recibió en su casa a Felipe II, quien contrajo allí matrimonio con Isabel de Valois ${ }^{14}$.

El hijo primogénito del IV duque, Diego Hurtado de Mendoza, nació en Guadalajara en 1520 y murió en Toledo en 1560, sin llegar a heredar el Infantado. Fue, en consecuencia, conde de Saldaña, heredero ducal y padre del V duque. Casó en 1535 con María de Mendoza, hija menor del famoso Rodrigo —el hijo del Gran Cardenal-, por lo que ostentó también el marquesado del Cenete a la muerte sin descendencia de Mencía (1554). El título se unió definitivamente al del Infantado en la persona de su hijo el $V$ duque. Recibió nuestro Diego una educación muy parecida a la de su progenitor y, aunque no tengamos demasiados datos al respecto, parece haber seguido de cerca sus pasos. Viajó siendo niño a Italia junto a su padre en la jornada de la coronación imperial en Bolonia, y vivió rodeado de un ambiente cultural y cortesano muy apropiado, en el ámbito paterno y, quizás, en el de su cuñada y anterior titular del marquesado del Cenete, Mencía de Mendoza ${ }^{15}$. Diego falleció como consecuencia de un choque en una justa, de las que tuvieron lugar con motivo de las celebraciones por el matrimonio de Felipe II con Isabel de Valois ${ }^{16}$.

\section{Las imágenes}

El estudio de las imágenes que pertenecieron a los tres personajes de los que nos hemos propuesto ocuparnos aquí, se distribuirá de forma que, primero, nos ocuparemos de las distintas piezas y objetos de esta categoría, atendiendo al aspecto descriptivo que ofrecen los documentos, caso por caso. Para ello, en principio, deberemos atenernos a las divisiones internas de las fuentes o a las clasificaciones necesarias para un desarrollo coherente del discurso. Una vez clarificado el número, tipología, significado, iconografías, tamaños y distribuciones espaciales, entre otras variables, procederemos a interpretar dichas variables en orden a dar una explicación global y, como objetivo fundamental, valorar si se produjo una evolución intergeneracional $y$, si esta efectivamente se produjo, cuáles son sus características. Ello nos permitirá aproximarnos bastante al grado y al ritmo de la adopción de la cultura modernorenacentista en la casa ducal del Infantado en el período que nos corresponde.

Dos cuestiones de especial relevancia debemos tener en cuenta, además. Primero, que las colecciones son personales, lo cual quiere decir que no son elencos acumulativos que pasaran de padres a hijos, salvo excepciones. Cada uno de los personajes que nos corresponden debió normalmente iniciar un nuevo grupo de objetos, ofreciendo de paso un mayor reflejo de sus intereses culturales resultado de su formación y de 
las corrientes de interés en su tiempo. Por otra parte, tanto al proceder a la exposición descriptiva, como al análisis explicativo de los datos, especialmente a la hora de valorar el número de piezas y su tamaño, separaremos los tapices del resto de las imágenes. Esto se debe a las especiales características físicas de los grandes paños, así como a su carácter funcional y de uso, manifiestamente diferente a los de las otras imágenes.

El III duque del Infantado, según indica el inventario post mortem de sus bienes ${ }^{17}$ y otras fuentes complementarias ${ }^{18}$, reunió un total de nueve pinturas y siete esculturas, lo que ofrece un total de dieciséis imágenes, sin los tapices. Atendiendo ahora fundamentalmente a la cuestión de su uso, y a la información ofrecida por el documento principal, nos centraremos primero en los formatos y en las iconografías. El inventario señala en primer lugar la existencia de una Nuestra Señora grande y, después, una Nuestra Señora "de la noche", al parecer pinturas sobre tabla. En el palacio ducal había también por lo menos dos retablos de imágenes. Según parece, uno representaba la Adoración de los Reyes y el otro la Quinta Angustia (Piedad), este último específicamente recogido en la capilla. También formaba parte de las propiedades del duque un Ecce Homo "de cinta". Como puede verse, siguiendo como seguimos las partidas del inventario, todas las piezas están descritas de forma muy escueta. Otras obras están descritas más someramente aún. Se recoge la existencia de una imagen entera "de Rincón", una tabla redonda "de imagen", y un retablo pequeño, sin que se nos aporte más información. También se indica la presencia de unas tablas con cuatro imágenes, sin que por esta fuente podamos saber lo que representaban. Afortunadamente, en otro documento se señala que representaban asuntos relacionados con la Virgen ${ }^{19}$. Aparentemente, ninguna otra imagen de pintura formaba parte de las posesiones del III duque del Infantado, a tenor del contenido de los documentos que manejamos. Una fuente literaria ya aludida (la obra de Zapata), se refiere a una pintura de complicado tema alegórico que se encontraría supuestamente en el palacio del Infantado el año del recibimiento de Francisco I de Francia. Pero debemos tener cuidado, porque se trata de una fuente de carácter literario, muy fantasiosa y sin mucho peso testimonial ${ }^{20}$. Por esta razón, y porque el cuadro alegórico no aparece recogido en los inventarios ni otros documentos, no lo tendremos en cuenta a la hora de las interpretaciones de los datos.

Las esculturas que reseña el inventario eran cinco piezas de plata y dos alabastros. Las primeras tenían pesos de entre 25 y 37 marcos, y representaban una a la Virgen, otra a san Juan, dos a san Pedro y otra a Santiago. Los alabastros eran una figura del Niño Jesús en su caja de madera, y otra de Nuestra Señora. En conjunto, se trataba sobre todo de obras de tipo religioso, y quizás de una dotación algo escasa para el palacio de una casa ducal de la importancia de la del Infantado.

Los tapices del III duque formaron un conjunto extraordinariamente grande y de gran riqueza material. En total, se trataba de nada menos que de 69 paños y 6 antepuertas, que alcanzaban una superficie de cerca de 3.734 anas (1 ana-0'700 metros aprox.) y un enorme valor económico. Los tapices se recogen en los inventarios formando diversos conjuntos o tapicerías. Registrada en primer lugar tenemos la de Tánger y Arcila. A continuación se reseñaron la de Alejandro ("alixandrie"), de José ("Josepe"), otra denominada de "la Reyna" que representaba iconografías del "triunfo de Ercoles", otra llamada de "plaçuela", otra de boscaje, otra llamada de los meses, una más denominada de "cabron" y otra de Haman, así como varios paños viejos que estaban en la "saleta". Había también piezas sueltas, como un paño de Nabucodonosor, otro grande viejo de montería (que estaba roto), otro viejo de la Fama, otro viejo de sobrecama, un paño que se llamaba "de la maroma", otro "de tapiz", uno más "que se dize de Yñigo Lopez", el siguiente "que se dize del cruçifixo", un paño "del unicornio", varios tapices de "arboledas", otro tapiz viejo "que se dize de Alvaro de Luna", otro paño grande de montería, y varios reposteros con decoración heráldica ${ }^{21}$. Además de estos que se relacionan en el apartado correspondiente a los tapices del inventario principal, tenemos otros ejemplares en partidas aisladas del inventario y de un anexo realizado en 1532 . Se trata, sin embargo, de piezas menores, salvo quizás un dosel de tapicería de la Pasión. En el anexo al inventario apa- 
rece un juego de cinco paños de verduras más un tapiz de figuras, viejos.

Tanto el contenido como el formato y el uso de los tapices del III duque del Infantado (veíamos usos concretos en el palacio de Guadalajara) indican que se trataba del gran conjunto de tapices propio de una gran casa señorial, su orgullo y el principal modo de dignificar las salas y dependencias de la residencia señorial. Los temas son bastante comunes, pues los tapices, salvo en raras ocasiones, no se encargaban, sino que procedían de almonedas y del mercado flamenco. Es más excepcional el caso de los tapices de Tánger, que fueron encargo ex profeso portugués - no se sabe a ciencia cierta cómo acabaron en manos de los Mendoza-, aunque también fueran de manufactura flamenca ${ }^{22}$. Incluso, parece que varias de las piezas antiguas eran de procedencia familiar, a tenor de sus denominaciones. Los reposteros con las armas de los Infantado sí que eran encargos realizados directamente a los artesanos, aunque serían de manufactura peninsular.

El IV duque del Infantado consiguió recopilar un número bastante aceptable de imágenes, aunque no fuese demasiado amplio, si lo comparamos con las que fueron propiedad de alguno de sus congéneres contemporáneos ${ }^{23}$. No alcanzó cantidades como la del duque de Medina Sidonia fallecido en 1558, otro componente de la alta nobleza de la categoría de los grandes, quien llegó a poseer ciento once obras de pintura y dieciséis de escultura ${ }^{24}$. En los documentos de inventarios de bienes de Îñigo López de Mendoza aparecen reflejadas treinta y dos partidas referidas a imágenes. En primer lugar nos encontramos con una medalla de oro con la representación de una mujer con una serpiente en un brazo y un espejo en la otra mano, seguramente una alegoría de la Prudencia. En la capilla de su residencia había una Virgen con el Niño en brazos "de pinzel" grande "del mayorazgo", así como otra Virgen con el Niño en brazos con puertas en las que estaban representados san Gregorio y san Juan Bautista. En un apartado que recoge los bienes presentes en la recámara de un hijo del IV duque, Alonso de Aragón, se encuentra una partida que recoge una imagen de un Ecce Homo bordada de oro y seda sobre terciopelo negro. Más adelante, el inventario alude a varios lienzos pintados, uno de Flandes con la Historia de Daniel, otro pequeño "en que están pintadas siete figuras las qtro A una pte y las tres a otra pies con cabeza" y otro con las armas de Mendoza con el toisón de oro sostenidas por leones rampantes, que había pintado un tal Juan de Festes. A todo ello debemos sumar la existencia de varios retablos pequeños, que serían de devoción privada: uno era más bien mediano, con representación de la escena culminante de la Pasión (concretamente, el Crucificado y los dos ladrones), otro era pequeño con la representación de las Plagas y un otro era un díptico pequeño con la Crucifixión y el Descendimiento.

Entre las imágenes del IV duque encontramos ya formatos y géneros temáticos pertenecientes a nuevos horizontes culturales. Si hemos visto alguna pintura sobre lienzo, ahora nos encontramos con la aparición de los retratos. Poseía el de su hijo el marqués del Cenete y conde de Saldaña, dibujado en papel. También el de su yerno Francisco de Guzmán, conde de Belalcázar, en tabla de pino. A ellos se sumaba el de su hija la marquesa de Aguilar, en lienzo. Finalmente, varias partidas del inventario se refieren a varios retratos sin identificar, pues únicamente se dice que eran de una mujer casada, de una viuda y de una doncella. Como colofón, el IV duque del Infantado poseía su propio retrato, pintado en tabla ("retrato en una tabla de noguera del Sor. don Iñigo de Mendoza"). Otras partidas que ofrecen alusiones interesantes en lo relativo a las imágenes son las que se refieren a dibujos. Aparte del que era retrato de su hijo y heredero, encontramos varios más de distintas armas y piezas de armadura, un libro de imágenes dibujadas, y diversos papeles dibujados conservados en un cofre. También encontramos, asentados en lienzo para su exposición, un mapamundi grande y una vista de Roma, ambos pintados sobre papel ${ }^{25}$. Más adelante encontramos un porcentaje bastante amplio de imágenes de escaso valor material, como dos verónicas y un san Francisco en pergamino, otros dos san Franciscos más, uno en papel y el otro de alcorza, y una lámina de metal - "estampa" - con la representación de la Asunción. Se trataría de imágenes de devoción. El inventario recoge también la existencia 
de pequeñas esculturas. Dos eran de alabastro, con representaciones del Niño Jesús y un santo, otro Niño Jesús, que era de vestir, y un Cristo a la columna. Finalmente, otras dos esculturas eran de yeso (un "nro Señor") o de madera (un san Gerónimo).

Hemos visto que una de las piezas importantes de la capilla se describe como perteneciente al mayorazgo. Esto es, que se había convertido en inalienable ligándola a los bienes pertenecientes al título nobiliario. No sabemos si esto se produjo durante la vida del IV duque, quien la habría adquirido o, como parece más probable, nos encontremos ante la misma imagen de Nuestra Señora Grande propiedad del III duque. Lo raro del caso es que el documento del inventario señale que "se diçe" del mayorazgo, y que aparezca registrada en el inventario de bienes libres. Podemos suponer que, dado que no aparece tasada tras la muerte del III duque, éste la vinculó a los bienes del mayorazgo antes de su muerte, y que se inventariara ahora por error ${ }^{26}$. Otra pieza que parece haberse conservado también, seguramente por motivos devotos, sería el Ecce Homo textil, que sería seguramente el que acompañó en el lecho de muerte al III duque. Lo demás de la herencia se había vendido para afrontar las mandas testamentarias y las deudas del finado, aunque veremos que con matices importantes. En lo que se refiere a imágenes de pincel, el IV duque debió rehacer la dotación litúrgica de la capilla con otra pintura de la Virgen con el Niño, así como adquirir diversos retablos pequeños para completar esa dotación o dedicarlos a su devoción privada.

Al referirnos a los tapices debemos aludir a un hecho poco habitual. En principio, los bienes no pasaban al heredero si no estaban vinculados al mayorazgo, por lo que normalmente debían ser vendidos para hacer frente a las necesidades de la herencia y satisfacer deudas. Como mucho, el heredero del título podía acudir como un comprador más a la almoneda para intentar adquirir algún bien que le resultase precioso. Pero en el caso que nos ocupa encontramos un procedimiento poco convencional para conservar parte de la herencia "libre" paterna ${ }^{27}$. Lo normal hubiese sido que los tapices de su progenitor se hubiesen vendido y que quizás hubiera podido retener alguno mediante compra $^{28}$. Pero el IV duque del Infantado, por motivos que no podemos concretar, pero que tendrán que ver con el aprecio que sentía por muchas de las piezas que habían pertenecido a su padre, actuó contra lo estipulado no entregando estos y otros bienes para que se vendieran en la almoneda. Retuvo en Guadalajara casi toda la tapicería, además de otros bienes, por lo que fue denunciado ante los tribunales por los acreedores del III duque. No podemos detenernos ahora en los detalles del proceso que se desarrolló ante la Real Chancillería de Valladolid, por lo que nos limitaremos a señalar que, finalmente, el duque consiguió retener las piezas de la tapicería comprometiéndose a abonar una abultada cantidad (casi millón y medio de maravedíes). De esta forma evitó perder tapices en una almoneda en la que podía haber participado, aunque en teórica igualdad de condiciones con otros compradores y, de paso, que el precio se hubiera hecho inalcanzable en las pujas, pese a lo cual finalmente el desembolso fue muy fuerte ${ }^{29}$.

Es por todo ello por lo que grandes tapicerías, como el conjunto de Tánger y Arcila, que sería el más valorado en tanto que vinculado a la familia por razones más allá de las legales o económicas, el de los Triunfos de Petrarca, el de "la Reina" de Historias de Hércules, el de Alejandro, los paños de José, los llamados de Haman, los de la saleta, el de Nabucodonosor, el paño de la maroma, los de plazuela, el tapiz de figuras, y otros menores, pasaron del III al IV duque del Infantado ${ }^{30}$. De todas formas, el IV duque no se limitó a adquirir de esa peculiar manera los tapices de su antecesor, sino que se dedicó con fruición a la adquisición de más piezas, teniendo incluso un agente en Bruselas para el asunto. Según los documentos del inventario post mortem y otros, al final de la vida del duque algunos de aquellos paños de su padre ya no estaban en su poder. Seguramente, dado que varios de ellos eran viejos y se deteriorarían irreversiblemente, se acabarían desechando.

Lógicamente, y según lo que hemos señalado, en dichos documentos aparecen partidas referidas a tapices nuevos. Gracias a la dote de su esposa, pudo añadir a su conjunto de piezas de tapicería un conjunto de Mucio Scaevola. 
Además, ahora se sumaban diversos paños de Tournai, algunos tapices con figuras aisladas y otro grupo de paños de verduras o de "lampazos" (decorativos, con representaciones vegetales). Finalmente, su conjunto de tapicerías alcanzó la cantidad de noventa piezas, sesenta y nueve de ellas tapices y el resto ejemplares menores, como antepuertas, con una superficie de 1.737 anas y 916 varas cuadradas. De ellos, más de treinta piezas eran de temática profana, mientras que veintidós mostraban temas religiosos, que ya hemos visto en general (pues eran los de su padre en su mayoría). Los había con temas mitológicos, aunque pocos, destacando Hércules, Venus o las Amazonas. Los había de historia antigua, de Alejandro o Mucio Scaevola. $Y$ el resto de los temas profanos son tan variados que no se pueden agrupar, salvo quizás en el caso de las alegorías o los temas de género ${ }^{31}$.

Llegado a este punto, nos quedan por ver las imágenes que fueron propiedad de Diego Hurtado de Mendoza, conde de Saldaña y marqués del Cenete. De entrada, debemos hacer un par de consideraciones con respecto a este personaje que afectan a la comprensión de su conjunto de pinturas, tapices y demás imágenes. En primer lugar, aunque fue el heredero del IV duque, ya hemos visto que falleció varios años antes que su padre. Esto nos obliga a ignorar la estricta lógica de la ordenación cronológica, pues hemos de pensar en que, a pesar de ello, era una generación más joven que su progenitor y, si no cronológicamente, sí que sociológicamente corresponde el estudio de sus bienes al final. En segundo lugar, es importante comprender que, al no llegar a heredar el ducado del Infantado, su posición social y económica no llegó realmente a alcanzar la de sus antecesores, con las consecuencias que podemos deducir a la hora de valorar sus posesiones.

Los inventarios nos señalan que, sin tener en cuenta los tapices, llegó a poseer al final de su vida cincuenta y una pinturas y dos libros de retratos dibujados ${ }^{32}$. En los registros de bienes encontramos estas obras anotadas en dos grupos, tras un par de obras que aparecen sueltas un poco antes. El primero, bajo el encabezamiento "lienços", es bastante amplio y dominado por la temática religiosa veterotestamentaria. El segundo grupo de pinturas se registró más adelante, situado en la recámara de la marquesa del Cenete y condesa de Saldaña, dominado por una temática nueva y mucho más moderna: la mitológica.

En primer lugar, los inventarios indican la existencia de un lienzo con dos figuras (hombre y mujer). Después, algo más adelante, encontramos un "retrato" de Lucrecia, una heroína de la Antigüedad, seguido del amplio grupo de pinturas anotadas bajo el encabezamiento "lienços", que señalábamos. Se trataba de siete lienzos grandes de la Creación del mundo, otros cinco del Diluvio y Arca de Noé (formaban series), un Triunfo de José, un David y Abigail, un Sacrificio de Isaac, una Serpiente de metal del desierto y un David y Betsabé en el terreno del Antiguo Testamento, y una Aparición en el camino de Emaús, un Hijo pródigo, un San Francisco "con unos lexos grandes", ocho virtudes, una alegoría de la Misericordia en lienzo grande y otra de la Juventud. Junto a ellos, había representaciones de hechos de armas contemporáneos, como las representaciones de la batalla de San Quintín y toma de Châtelet por Felipe II, un papel forrado en lienzo con el ejército del Turco y dos mapamundis. Como ejemplo de la pintura de género encontramos un lienzo pequeño de una flamenca llevando cántaros en la cabeza.

Mucho más adelante, en un apartado diferente, tras los libros y otras cosas, encontramos los otros "lienços pintados". Muchos de ellos presentaban temas mitológicos, como las historias de Dánae, Marte, Venus y "melusa", el Juicio de Paris, Europa, y Venus ${ }^{33}$. Casi todos los episodios, además de mitologías por lo general tomadas de las Metamorfosis de Ovidio, mostraban episodios de desnudos y especial contenido erótico, lo que resulta realmente interesante cuando recordamos que se encontraban en la recámara de la marquesa ${ }^{34}$. Este segundo grupo de obras mostraba, además, temáticas de otro tenor y gran diversidad, como un cuadro de Job, otro de un fraile que azotaba a una monja, otro de la "Historia de la Caridad" y otro de unos Judíos pintados. El agrupamiento no parece tener una lógica interna una vez superado el grupo temático mitológico, pues ahora encontramos tanto - como en el primer grupo- la historia veterotestamentaria, junto a alegorías y escenas cotidianas. No sabemos exactamente 
qué escena representaba el cuadro de Job, pero el tema del fraile y la monja pudiera estar ligado al de la erótica de los mitológicos. Tampoco tiene mucho sentido, aparentemente, situar aquí una alegoría de la Caridad, o el cuadro de los judíos, al menos con los datos que nos dan las fuentes.

Finalmente, tenemos el género del retrato representado por algunos ejemplares. Ciertamente, no parece que se tratara de retratos de aparato, ni de la formación de una galería familiar, pese a lo cual debemos valorar su presencia positivamente. Los inventarios recogen la presencia de dos pinturas sobre tabla, una con la representación de la marquesa del Cenete, seguramente la consorte de nuestro personaje, y otra de la princesa de Éboli $i^{35}$. A estas escasas piezas, que debemos suponer de pequeño formato dado que estaban cada una en su caja, hemos de sumar dos libros "de retratos debujados". La posesión de estos ejemplares parece indicar un gusto especialmente refinado y selecto a la hora de entender la imagen del individuo, más que como galería expuesta, como imagen susceptible de ser contemplada y provocar la reflexión más íntima. Finalmente, como piezas dedicadas a la devoción particular tenemos una imagen de san Gregorio en una caja y una Verónica.

Los tapices que pertenecieron al heredero del IV duque, presentan la particularidad de que no podían en ningún caso ser un elenco heredado, ni siquiera aunque se hubieran vinculado de alguna forma al mayorazgo. Porque, como hemos señalado ya, nuestro conde de Saldaña y marqués del Cenete falleció antes que su progenitor. Los documentos nos indican que poseyó un juego de seis grandes piezas con la historia de David, además de otro conjunto de seis tapices eran de los Triunfos de Petrarca, otro que representaba la Ciudad de las Damas y el siguiente la historia de Alejandro ${ }^{36}$. Sólo estos grandes conjuntos sumaban más de 1.229 anas de medida. Además, debemos considerar un juego de tapices pequeños de la historia de José y otro de ocho piezas la de Tamar. Otros muchos paños eran piezas menores, de verduras (decoraciones vegetales) o heráldicos.

\section{La explicación}

Una vez expuestos los datos relativos a las imágenes poseídas por los tres miembros de la saga, nos queda enfrentarnos a esa información de manera interpretativa y global. Al igual que hemos hecho arriba, al separar el análisis de los datos relacionados con tapices y resto de imágenes, ahora debemos ofrecer una explicación también por separado, dejando los grandes paños para el final. En un primer acercamiento notaremos que se ha producido un lento pero progresivo aumento del número de imágenes que no son tapices desde el III duque hasta su nieto. La evolución cuantitativa va del número de dieciséis a treinta y dos piezas, finalizando el recorrido en cincuenta y una. Hemos podido comprobar también que no sólo el número sufre una evolución, sino también la temática y el formato de aquellas imágenes. Las iconografías puramente devocionales y litúrgicas -además, repartidas entre esculturas y pinturas - y formatos tales como los retablos, se han ido sustituyendo por formatos y modelos más evolucionados. El III duque del Infantado demuestra haber poseído únicamente retablos, imágenes sobre tabla y otros ejemplares, como esculturas de plata, con el prácticamente exclusivo fin y uso de dignificar las celebraciones litúrgicas de su capilla, así como de haber ofrecido soporte contemplativo a la religiosidad privada. Sin que, lógicamente, en el caso del IV duque hayan desaparecido los retablos y las imágenes de devoción, la aparición con éste de las pinturas sobre lienzo de Flandes, como la que representaba a Daniel, así como los retratos de miembros de la casa ducal, e incluso los dibujos, nos van matizando el escenario de forma que los nuevos usos se notan en progresivo avance en los hábitos y costumbres de la modernidad. Los usos de los lienzos, normalmente más grandes y más manejables, aun teniendo temática religiosa, nos ponen ante criterios de despliegue iconográfico y decorativo de carácter mucho más público que los tradicionales. Otro avance lo tenemos en la aparición de retratos de personas vinculadas por relaciones familiares a la casa, e incluso el retrato del propio señor. Avanzando el siglo, la dotación de las residencias nobiliarias con una galería de retratos familiares se haría cada vez más importante en el universo de los grandes ${ }^{37}$. También la posesión de mapas indica el camino que se seguía en ese 
sentido. El resto de imágenes del IV duque son de tamaño, material y formato poco relevante. Quizás, dado que son de tipo religioso, estén ligados a la religiosidad católica tradicional, con el predominio de las imágenes de Cristo y de san Francisco, tan ligado a los Infantado. La iconografía de las esculturas no se aparta demasiado, con la excepción de la imagen de san Jerónimo ${ }^{38}$.

Pero realmente se da un salto cualitativo cuando nos encontramos con las pertenencias del marqués del Cenete y conde de Saldaña. Además del incremento numérico de piezas, nos encontramos con la desaparición de elementos de la cultura tradicional en el uso de las imágenes como los retablos de capilla o con puertas, además de con la parcial ausencia de las piezas de devoción particular en formatos "modestos". Con la llegada de la plena cultura de la modernidad encontramos formatos completamente diferentes, como son los cuadros sobre lienzo en práctica exclusividad, a veces formando grandes conjuntos, y ofreciendo temáticas que, sin dejar de tocar lo religioso, amplían sus registros a la historia antigua (donde se incluía entonces la veterotestamentaria), la mitología, los hechos contemporáneos e, incluso, los temas de género ${ }^{39}$. El uso, por decirlo así, conyugal de las pinturas de desnudos — situadas en la recámara de la marquesa del Cenete-, nos habla bien a las claras de un gran salto cualitativo a la hora de valorar modelos de comportamiento plenamente insertos en la cultura de la modernidad renacentista.

Encarando el campo de los tapices, notamos una evolución paralela en lo relativo al incremento numérico y de volumen, pero en sentido opuesto. La disminución es muy acusada al pasar del III al IV duque, sobre todo considerando que éste se quedó con la tapicería del antecesor. Igual de significativo es el descenso en el siguiente cambio generacional, aunque el marqués del Cenete es un caso atípico, pues no llegó a heredar el título principal. Podemos concluir que, aunque los tapices nunca dejaron de formar parte de las dotaciones de la casa nobiliaria, parece claro que en el camino de la modernidad se vieron progresivamente desplazados por otros elementos en las escenografías domésticas, los mismos que iban ganando terreno $y$, finalmente, constituyendo el núcleo de todo elenco de prestigio: las pinturas sobre lienzo. El tapiz siempre se vincula a modelos de tipo medieval en el despliegue de imágenes en interiores domésticos de la nobleza, aunque aún en el siglo XVI eran el elemento predominante y más importante (y lo serían bastante tiempo aún) de las escenografías domésticas de la aristocracia. El descenso de su número y su sustitución parcial en el caso que nos ocupa, se puede proponer como indicador de la adopción de modelos de la nueva civilización. En cuanto a los temas que éstos representaban, no encontramos grandes diferencias o evolución. Pero, bien es cierto que salvo por algún caso excepcional, los grandes conjuntos de tapices no se encargaban y el número de iconografías no era demasiado extenso. Es decir, que no había demasiado donde elegir y el grado de coincidencia fortuita suele ser, en general, bastante elevado al estudiar las colecciones nobiliarias hispanas. 


\section{NOTAS}

1 Este artículo se ha realizado dentro del proyecto de investigación I+D del Ministerio de Ciencia e Innovación, Ref. HAR2009-09231 (subprograma ARTE).

${ }^{2}$ Véase, a este respecto, la deriva de los estudios sobre la historia del coleccionismo desde Julius von Schlosser Die Kunst und Wunderkammern der Spätrenaissance. Leipzig, 1908 (ed. española Madrid, 1988). Una buena puesta al día metodológica y bibliográfica, en la introducción del libro de Urquízar Herrera, A. Coleccionismo y nobleza. Signos de distinción social en la Andalucía del Renacimiento. Madrid, 2007. El primer análisis global de conjunto en el caso hispano en Morán, M. y Checa, F. El coleccionismo en España. De la cámara de maravillas a la galería de pinturas. Madrid, 1985. Con interés en realizar una síntesis global del tema Cano de Gardoqui, J. L. Tesoros y colecciones. Orígenes y evolución del coleccionismo artístico. Valladolid, 2001.

${ }^{3}$ Debe tenerse en cuenta que no todas las ramas de la familia Mendoza, ni gran parte de sus individuos, parece haber participado en el mismo grado de esas tendencias de modernidad. Véase, al respecto, Marías, F. "Los Mendoza y la introducción del Renacimiento en España", en Nobleza, coleccionismo y mecenazgo. Sevilla, 1998, pp. 29-44.

${ }^{4}$ Tenemos una interesante visión crítica de los estudios sobre "coleccionismo" en España, en Urquízar Herrera, A. Op. cit., pp. 17-19. Casos excepcionales dentro de la alta nobleza hispana en lo relativo a modos excepcionalmente avanzados de "poseer" son, por ejemplo, el I marqués de Tarifa o el marqués del Cenete y su hija, y heredera, Mencía de Mendoza, por poner dos ejemplos destacados.

${ }^{5}$ Sobre el III duque del Infantado, tenemos a Núñez de Castro, A. Historia Eclesiástica y Seglar de la muy noble y muy leal ciudad de Guadala- xara. Madrid, Pablo del Val, 1653, p. 158 y ss. También Gutiérrez Coronel, D. Historia genealógica de la Casa de Mendoza. Ed. de A. González Palencia, Madrid, CSIC, 1946. López de Haro, A. Diccionario genealógico de los reyes y títulos de España. Madrid, Viuda de Fernando Correa de Montenegro, 1622, tomo I, p. 248. Todavía manuscrito, tenemos la obra del que sería XIII duque del Infantado, aún como marqués de Tavara: Toledo Silva Mendoza, P. de. Linaje de Mendoza. Biblioteca Nacional Madrid, Mss. 11461, $2^{a}$ parte, lib. 19. Véase Arteaga y Falguera, C. de. La casa del Infantado, cabeza de los Mendoza. Madrid, 1940, tomo I, pp. 271.

$$
{ }^{6} \text { Núñez de Castro, A. Op. cit., p. }
$$
158.

7 Op. cit., pp. 172-173. Véase Zapata de Chaves, L. Carlo famoso. Valencia, Juan Mey, 1566 (ed. de Manuel Terrón, Badajoz, 1981). Sobre la entrada, véase también Castañeda y Alcover, V. La entrada del rey Francisco de Francia en Guadalajara. Madrid, 1918. Recientemente Carrillo Castillo, J. y Pereda Espeso, F. "El caballero: identidad e imagen en la España imperial ", en Carlos V, las armas y las letras. Madrid, 2000, pp. 183-200.

${ }^{8}$ Arteaga y Falguera, C. de. Op. cit., tomo I, pp. 317, quien lo toma de Núñez de Castro, A. Op. cit., p. 179.

9 Véase Pecha, H. Historia de Guadalaxara y cómo la Religión de San Gerónimo en España fué fundada y restaurada por sus ciudadanos. (BN. mss. 1756) edición Guadalajara, 1977 p. 292. Núñez de Castro, A. Op. cit., p. 180. Arteaga y Falguera, C. de. Op. cit., tomo l, p. 321 y ss.

10 López de Mendoza, Í. (IV duque del Infantado) Memorial de cosas notables. Guadalajara, Pedro de Robles y Francisco de Cormellas, 1564. Especialmente el prólogo

11 Pecha, H. Op. cit., p. 293. Núñez de Castro, A. Op. cit., p. 181.

${ }^{12}$ Gil Ayuso, F. El equipo de boda de doña Isabel de Aragón. Madrid, 1934. Véase Arteaga y Falguera, C. de. Op. cit., tomo I, p. 325. Última- mente: Serrano Cueto, A. "La boda de Íñigo López de Mendoza (IV duque del Infantado) e Isabel de Aragón cantada en verso latino por Martín Ivarra", en Estudios de humanismo y tradición clásica. No. 5 (2006), pp. 361-385.

13 Gracián, D. La Coronación Imperial con todas sus cerimonias traduzida de latín en lengua castellana. S. I., 1530; Bernardez, A. Enrique Cornelio Agripa. Filósofo, astrólogo y cronista de Carlos V. Traducción al castellano de la Historia de la doble coronación del emperador en Bolonia. Madrid, 1934; Mexía, P. Historia del Emperador Carlos V. Ed. Madrid, 1945; Sandoval, P. de. Historia de la vida y hechos del Emperador Carlos V. Ed. Madrid, 1955, 2 vols; Contreras, J. de (marqués de Lozoya) La coronación imperial de Carlos V. Madrid, 1958; Chastel, A. "Les Entrées de Charles Quint en Italie", en Jacquot, J. (coord.) Les Fêtes de la Renaissance. París, 1960, II, pp. 197-206; Bosbach, F. "Zeit geschichte im Werk Girolamo Balbis: Die Kaiserkrönung Karls V. in Bologna (1530)", en Memores Tui. Sassoferrato, 1990, pp. 21-44; Kagan, R. L. "Los cronistas del emperador", en Navascués Palacio, P. (ed.) Carolus $\checkmark$ Imperator. Barcelona, 1999, pp. 213-25; VV. AA. La Imagen Triunfal del Emperador. La jornada de la coronación Imperial de Carlos V en Bolonia y el friso del ayuntamiento de Tarazona. Madrid, 2000.; Kohler, A. Carlos V (1500-1558). Una biografía. Madrid, 2000 .

${ }^{14}$ El recebimiento, que la Vniuersidad de Alcala de Henares hizo a los Reyes nuestros señores, quando vinieron de Guadalajara tres dias despues de su felicissimo casamiento. Alcalá de Henares, Juan de Brocar, 1560.Gómez de Castro, A. Recebimiento que la Imperial Ciudad de Toledo hizo a la Magestad de la Reyna nuestra señora doña Ysabel, hija del Rey Henrico .Il. de Francia: quando nuevamente entró en ella a celebrar las fiestas de sus felicíssimas bodas, con el Rey don Philippe nuestro señor II. Deste nombre. Toledo, Juan de Ayala, 1561;Alenda y Mira, J. Relaciones de solemnidades y 
fiestas públicas en España. Madrid, 1903, vol. I; Huarte y Echenique, A. Relaciones de los reinados de Carlos $V$ y Felipe II. Madrid, 1941, vol. II, pp. 141-160; Simón Díaz, J. Fuentes para la historia de Madrid y su Provincia. Madrid, 1964, vol. I, pp. 1-7; Alvar Ezquerra, A. "Los recibimientos que Alcalá de Henares y Madrid tributaron a Isabel de Valois tras su boda con Felipe II", en I Jornadas de estudios sobre la provincia de Madrid. Madrid, 1979, pp. 693-700; Pizarro Gómez, F. J. Arte y espectáculo en los viajes de Felipe II. Madrid, 1999.

15 Sobre Mencía de Mendoza, véanse (las publicaciones más recientes, con bibliografía anterior): Martí Ferrando, J. "Una humanista en la corte virreinal: Mencía de Mendoza", en San Miguel de los Reyes: de biblioteca real a biblioteca valenciana. Valencia, 2000, pp. 73-89; Hidalgo Ogáyar, J. "Doña Mencía de Mendoza embajadora del arte español en Breda", en El arte español fuera de España. XI Jornadas de Arte del CSIC. Madrid, 2003, pp. 187-192; García Pérez, N. "La huella petrarquista en la biblioteca y colección de obras de arte de Mencía de Mendoza", en Tonos digital: revista electrónica de estudios filológicos. NN. 8 (2004); García Pérez, N. Mencía de Mendoza (1508-1554). Madrid, 2004; García Pérez, N. "Emoción y memoria en la biblioteca de Mencía de Mendoza: tres figuras para una respuesta", en Goya. 313-314 (2006), pp. 227-36. A pesar de heredar el mayorazgo -quizás por ello-, María de Mendoza y nuestro Diego, no fueron beneficiarios de los bienes libres de Mencía.

${ }^{16}$ Núñez de Castro, A. Op. cit., pp. 186-187; Pecha, H. Op. cit., p. 303; Gutiérrez Coronel, D. Historia genealógica de la Casa de Mendoza. AHN (Nobleza) Osuna, 3408 (1772) 3 vols. Existe edición, Madrid, 1946, p. 25; Arteaga y Falguera, C. de. Op. cit., I, p. 346. Los dos primeros con errores de bulto a la hora de informar sobre la fecha de fallecimiento de Diego.

${ }^{17}$ Archivo Histórico Nacional (en adelante AHN) (Nobleza). Osuna, leg.
1832, doc. 1. Inventario post mortem de Diego Hurtado de Mendoza, III duque del Infantado, 31 de agosto de 1531.

${ }^{18}$ Inventario-tasación de los bienes del III duque del Infantado, realizado en enero de 1532, AHN (Nobleza). Osuna, leg. 1832, doc. 4.

19 AHN (Nobleza). Osuna, leg. 1832, doc. 3, s. fo.

20 Véase la descripción de una pintura con una elaborada iconografía simbólica que ofrece, en su invención literaria, Zapata de Chaves, L. Op. cit. Aparece transcrito en Núñez de Castro, A. Op. cit., pp. 172-173.

${ }^{21}$ AHN (Nobleza). Osuna, leg. 1832, doc. 1, fol. $38 r^{\circ} y^{\circ}$, donde aparece recogida la mayor parte de la tapicería. Algunos ejemplares sueltos aparecen en diversos folios del documento. Véase en Suárez de Arcos, F. y Herrera Casado, A. "Tapicerías en la Casa de Mendoza", en Wad-al-Hayara. 14 (1987), pp. 215 (análisis, incluida la posible procedencia de los paños de "la Reina") y 224-229 (transcripción del apartado del inventario-tasación de 1533, dedicado a los tapices).

${ }^{22}$ Los tapices de Tánger y Arcila pasarían al IVy $\mathrm{V}$ duques, y a sus descendientes y, con la unión de las dos casas ducales de Pastrana y el Infantado, a Pastrana, en cuya colegiata se conservan. Sobre estas piezas, pueden verse, entre otras: Do Santos, R. As tapeçarias da tomada de Arzila. Lisboa, 1925; Dornellas. A. de. As tapeçarias de $D$. Afonso $V$ foram para Castela por oferta deste Rei. Lisboa, 1926; Dos Santos, R. As tapeçarias de Tanger. Lisboa, 1926; Figueiredo, J. de. As tapeçarias de Arzila e as relaçoes com os Paneis de Nuno Gonçalves. Lisboa, 1926; Pérez, L. Tratado histórico de los tapices de Pastrana. Toledo, 1927; García Merchante, E. Los tapices de $D$. Alfonso $V$ de Portugal. Toledo, 1929; Asselberghs, J. P., Demarcel, G. y García Calvo, M. "Un tapissier bruxellois actif en Espagne: François Tons", en Bulletin des Musées Royaux d'Art et d'Histoire. 56 (1987), pp. 89121. Últimamente: García Calvo, M.
Los tapices de Pastrana. Tesis doctoral UNED, 1995; García Calvo, M. "Dos tapices de cruzadas en la iglesia parroquial de Pastrana", en Goya. n. 293 (2003), pp. 81-90; Herrera Casado, A. Pastrana, una villa principesca. Guadalajara, 2005. pp. 81-83; Ferrer González, J. M. y Ramírez Ruiz, V. Tapices y textiles de Castilla-La Mancha. Guadalajara, 2007, pp. 206-223.

${ }^{23}$ Existen dos inventarios de los bienes del IV duque del Infantado, uno redactado en 1564, con motivo del fallecimiento de su esposa, y otro realizado al fallecer el duque mismo, en 1566. El primero de ellos corresponde a la signatura: AHN (Nobleza). Osuna, leg. 1834, doc. 2. El segundo, que incluye la tasación de los peritos sobre el valor de las distintas piezas: AHN (Nobleza). Osuna, leg. 1834, doc. 1.

${ }^{24}$ Urquízar Herrera, A. Op. cit., pp. $132-140$ y 175-207.

${ }^{25}$ Debemos destacar la importancia de los mapas como decoración o complemento escenográfico mural, y los ciclos cartográficos, que llegaron a ser pictóricos. Cfr. Schulz, J. "Maps as Metaphors: Mural Map Cycles of the Italian Renaissance", en Woodward, D. (ed.) Art and Cartography. Six Historical Essays. Chicago-Londres, 1987, pp. 97-122.

${ }^{26}$ En el testamento del III duque nada se dice al respecto de la tabla adscrita al mayorazgo, por lo que es muy posible que se adscribiera en fecha anterior, por instrumento público que no conocemos. Copia del testamento en AHN (Nobleza). Osuna, leg. 1763 , doc. 3

27 Sobre la vinculación o no de algunas piezas al mayorazgo y la venta en almonedas, véase: Urquízar Herrera, A. Op. cit., pp. 95-109.

${ }^{28}$ Lo más destacado de lo que retuvo el IV duque de los bienes libres de su padre fue el gran conjunto de tapices. Esto no quiere decir que sólo se quedara con estas piezas, pero el resto de lo que retuvo no tiene ni mucho menos la misma importancia. Entre lo que a nosotros más nos interesa aparecen una tabla con cuatro 
imágenes y la nuestra Señora de la "noche" en lo que se refiere a imágenes. Sin embargo, muy pocas de estas piezas llegaron realmente a convertirse en posesiones del IV duque. Desde luego, el objetivo principal parece haber sido el grueso de los tapices, pues no nos consta que imágenes, libros $u$ otros elementos llegaran realmente a conservarse entre sus propiedades. Vid infra.

${ }^{29}$ Un inventario de bienes que quedaron en poder del IV duque, y que formaban parte de los bienes libres de su padre y antecesor en AHN (Nobleza) Osuna, leg. 1832, doc. 2 (Valladolid, 10 de mayo de 1533). El registro por separado de los bienes del duque Diego que tenía su heredero, y los de éste (tapices especialmente), en íd. Osuna, leg. 1832, doc. 3. Cédula real, íd. Osuna, leg. 1832, doc. 5 (fechado en 1533). Relación de bienes en poder del IV duque de los pertenecientes a su padre, en íd. Osuna, leg. 2967 (parece sin terminar). Provisión del Consejo Real ganada por los acreedores de Diego Hurtado de Mendoza, duque del Infantado, para que se pagasen las deudas, y para que la Chancillería de Valladolid informase de lo que pasaba con los bienes del finado (Madrid, noviembre de 1533) íd. Osuna, leg. 1832, doc. 6. Inventarios y registros parciales de bienes de los citados en íd. Osuna, leg. 1832, docs. 7-11. Autos del pleito con inventario de los bienes (Valladolid, 1533) íd. Osuna, leg. 1833. Obligación de Íñigo López de Mendoza y Alonso de Vallejo, su contador y principal pagador, reconociendo la sentencia de la Chancillería y comprometiéndose a tomar cuenta de los bienes a los que nos estamos aquí refiriendo, así como obligación del duque en mancomún con el mercader de Guadalajara, para hacer frente al precio de la tapicería que se había apropiado el IV duque y que perteneció a su padre, según disposiciones del tribunal el 30 de diciembre de 1538, en íd. Osuna, leg. 3400 (3), letra W, escribano público Juan de Cifuentes, registro de escrituras del año 1538. Obligación del duque de que pagará 1.431.630 por los bienes que retenía, de los que habían sido de su padre, íd, Osuna, leg. 1832, doc. 12.

${ }^{30}$ Suárez de Arcos, F. y Herrera Casado, A. Art. cit., p. 217.

${ }^{31}$ Art. cit., pp. 230-138.

${ }^{32}$ Las fuentes documentales para el conocimiento de los bienes que atesoró este personaje, según lo que poseía a título de bienes libres al final de su vida, son fundamentalmente dos. La primera es el inventario post mortem, redactado en abril de 1560, y con la signatura: AHN (Nobleza). Osuna, leg. 1835, doc. 1. La segunda fuente documental es el inventariotasación de los mismos bienes, documento muy completo (y extenso) con la signatura: AHN (Nobleza). Osuna, leg. 1835, doc. 2. Véase González Ramos, R. "Imágenes, libros y armas. Tipología y significado de los bienes de Diego Hurtado de Mendoza, conde de Saldaña y marqués del Cenete (1520-1560)", en Anuario del Departamento de Historia y Teoría del Arte (UAM). 21 (2009), pp. 31-46. El apartado dedicado a las imágenes, pp. 3538.

${ }^{3}$ Ya se habían referido a este grupo de pinturas, tomándolas como el grueso de la colección de nuestro marqués-conde, Morán, M. y Checa, F. El coleccionismo en España. De la cámara de maravillas a la galería de pinturas. Madrid, 1985, p. 167.

${ }^{34}$ Véanse: Clark, K. El desnudo: un estudio de la forma ideal. Madrid, 1984; Portús Pérez, J. La sala reservada del Museo del Prado y el coleccionismo de pintura de desnudo en la corte española, 1554-1838. Madrid, 1998; Cordero de Ciria, E. "Mostrar el arte. Consideraciones sobre la cuestión del desnudo en España en los siglos XVI y XVII", en Boletín del Museo e Instituto "Camón Aznar". XLII (2003), pp. 29-65.

${ }^{35}$ Se trataba de la tercera marquesa del Cenete, María de Mendoza, y de la princesa de Éboli Ana de Mendoza y de la Cerda, portadora de tal título desde su matrimonio con Rui
Gómez de Silva en 1557. Hay que matizar que el documento dice que era un retrato de la princesa de "Alculi", y que nosotros hemos interpretado Éboli.

${ }^{36}$ Basado en la obra de Cristina de Pisan La Ciudad de las Damas, es un típico producto del mundo bajomedieval de galanterías y caballeresco. Fue escrito en 1405, aunque con un tema poco convencional, la defensa de las mujeres frente a quienes argumentaban su carácter no moral como género, su malicia intrínseca y otras lindezas características. Resulta muy interesante la galería de mujeres que desde la Antigüedad habían sobresalido en ingenio, arte, virtud y demás méritos y virtudes, parangonándolas con las de los hombres. Véase, sobre las tapicerías con esta representación: Bell, S. G. The Lost Tapestries of the City of Ladies. Christine de Pizan's Renaissance Legacy. Berkeley-Los ángeles, 2004. Sobre la obra literaria y su relación con el arte: Fernández González, M. E. "El conocimiento del pasado a través del 'Libro de la Ciudad de las Damas' de Christine de Pizan", en Anuario del Departamento de Historia y Teoría del Arte. XIX (2007), pp. 35-50. Parece lógico pensar que esta tapicería de la Ciudad de las Damas fuera la que tenía la misma representación y compró María de Mendoza en la feria de Medina del Campo en 1534, el año anterior al de su matrimonio con del conde de Saldaña. Véase ahora: Hidalgo Ogáyar, J. "Doña María de Mendoza: ejemplo de pervivencia del coleccionismo medieval en el siglo XVI", en Congreso Internacional Imagen y Apariencia. Murcia, 2008, página <<web>>: http://congresos.um.es/imagenyapariencia/11 08/paper/viewFile/1351/1331. (Está sin paginar).

${ }^{37}$ Sobre el retrato y su uso nobiliario, tanto como elemento apartado de la mirada pública, como protagonista de las galerías públicas de familiares y antepasados, véase Fletcher, J. "El retrato renacentista: funciones, usos y exhibición", en El retrato en el Renacimiento. (Cat. de la exp.) Madrid, Prado, 
2008, p. 85. De la misma autora "Coleccionistas, aficionados y el arte del retrato", en El retrato. Madrid, 2004, pp. 109-126. En la misma publicación colectiva, Burke, P. "Sociología del retrato renacentista", pp. 91-107. Para el caso inglés: Hearn, K. (ed.) Dynasties: Painting in Tudor and Jacobean England, 1530-1630. (Cat. de la exp.) Londres, 1995. Sobre la identidad colectiva y el retrato véanse: Klinger Aleci, L. "Images of Identity: Italian Portrait Collections of the Fifteenth and Sixteenth Centuries", en Mann, N. y Syson, L. (eds.) The image of the Indivi- dual. Portraits in the Renaissance. Londres, 1998, pp. 67-79; Woods-mardsen, J. "Introduction: collective identity/individual identity", en Rogers, M. Fashioning Identities in Renaissance Art. Aldershot, Ashgate, 2000, pp. 116; Belting, H. Antropología de la imagen. Buenos Aires, 2007, pp. 143 y siguientes (capítulo sobre "Escudo y retrato. Dos medios del cuerpo". Agradezco que me señalara algunos de estos títulos a Urquízar Herrera, A., del que puede verse la reseña al catálogo de la Expo. El retrato en el Renacimiento, en Goya. Revista de arte. № 328 (2009).
38 Los Jerónimos siempre aparecen muy unidos a los Mendoza. Sólo hay que pensar en sus relaciones con el monasterio de san Bartolomé de Lupiana, donde se enterraron varios de ellos, y habitualmente protegieron, algunas veces llegando a asumir el patronato (condes de Coruña).

39 Nótese que, como señalan Morán y Checa (Op. cit., p. 156), por esas fechas, la imitación del rey llevó a la afición por los cuadros de temática mitológica entre parte de la nobleza y, en general, entre los cortesanos. Cfr. Portús Pérez, J. Op. cit. 